Учитель - это зеркало. Если он настоящий, вы увидите свое отражение. Если нет - красивую раму. Х. Насреддин

\title{
МНЕ В ЖИЗНИ КРУПНО ПОВЕЗЛО - У МЕНЯ БЫЛ НАСТОЯЩИЙ УЧИТЕЛЬ
}

\author{
А. Я. Троцковский
}

$\mathrm{K}$ ак быстро летит время. Кажется, буквально позавчера состоялся разговор с Татьяной Ивановной.

- Саша, когда меня не будет, Вы напишите обо мне книгу.

Пытаюсь отшутиться:

- Татьяна Ивановна, живите долго. Да и о чем я могу написать?

- А вы подумайте. О чем-нибудь хорошем...

Прошли годы... Оглядываясь назад, понимаю, что «хорошего» хватило бы с лихвой, в особенности с учетом сегодняшнего времени и современных нравов, - на добрый десяток порядочных людей и на большую книгу.

Жалею только, что не перенял привычку Татьяны Ивановны вести дневник, позволившую ей написать воспоминания о работе в Москве и подготовить материал для книги о жизни в Сибири. Вот только, «если хватит сил», — говорила она. Не хватило...

Стерлись из памяти детали и нюансы разговоров с Учителем. Осталось только ни с чем не сравнимое чувство теплоты, заполняющее душу, когда речь заходит о Татьяне Ивановне. Осталось ощущение несказанного и в чем-то даже незаслуженного везения. Волею судьбы я оказался рядом с человеком, оценить масштаб личности и уровень профессионализма которого возможно в полной мере лишь по прошествии многих лет. Воистину, «большое видится на расстоянье...»

На моем жизненном пути встречались одаренные и даже талантливые люди. Но Татьяна Ивановна стоит наособицу. И дело здесь даже не в масштабах таланта, что, бесспорно, имеет место, а в уникальном сочетании человеческих и деловых качеств, в поистине удивительной гармоничности и целостности личности, богатстве ее духовного мира.

Для науки, конечно, более важны деловые качества ученого, тот след, который он в ней оставил. Помню, как Татьяна Ивановна мне говорила:
«Если ученый ушел из жизни, а введенные им в научный оборот понятия живут, то это был большой ученый». Для тех же, кто работал и общался с Татьяной Ивановной, по моим наблюдениям, ее деловые качества, высочайший уровень профессионализма, при всей их важности и значимости, отходили на второй план.

На первом плане - все лучшие качества русского интеллигента, нашедшие свое воплощение, как это ни удивительно, в одном человеке, доброта, душевность, простота, общительность, чувство собственного достоинства, непоказное отношение к народу. При этом - никакой многозначительности, «надутых щек» (распространенная в наш показушный век болезнь), резкое неприятие лицемерия и полное отсутствие гордыни, которая, как известно, не щадит даже очень умных людей.

Это - не преувеличение и не панегирик Учителю. Я готов подробно аргументировать свою позицию. Вот лишь несколько примеров, свидетелем которых мне довелось стать.

Конец 1970-х годов. Научная экспедиция в сельской глубинке Алтайского края. Татьяна Ивановна работает в моем отряде в качестве рядового интервьюера. Хочет лично убедиться в надежности и работоспособности инструментария (анкеты). Утром на следующий день после проведения интервью ко мне подходит пожилая женщина, в руках держит очки.

— Вчера у меня была Ваша старушка, вот очки забыла...

- Какая старушка?

- Ну она еще меня спрашивала, что я читаю по вечерам. Я ей и говорю: возьму книгу, в глазах все плывет, не могу, засыпаю. Она мне сказала, что у нее все точно так же...

- Академик что ли? Татьяна Ивановна?

- Кто академик?

Надо было видеть лицо сельской женщины... Очки Татьяне Ивановне я передал. 
Начало 90-х годов. Российский народ не понаслышке знакомится с рынком, переживая, мягко говоря, непростые времена. Не помню, что послужило причиной, но сам диалог в силу его своеобразия крепко врезался в память.

- Саша, Вы знаете, почему я не покупаю себе новое пальто? Деньги у меня есть, вот я премию большую получила (Татьяна Ивановна накануне разговора стала лауреатом Демидовской премии). Мне неудобно перед своими подругами - они совсем пообносились...

Ни до, ни после я в своей жизни ни разу не встречал в таком концентрированном виде проявления интеллигентности.

По этому случаю вспоминается современная байка о «слабом» поле. Почему женщина покупает себе новое платье? В двух случаях: 1) когда оно у всех есть; 2) когда его нет ни у кого. Может быть, и несколько обидная для женщин байка, но она не про моего Учителя.

Середина 1990-х годов. Татьяна Ивановна преподает в Московской высшей школе социальных и экономических наук разработанный ею эксклюзивный курс «Трансформационные процессы в России: сущность, субъекты, внутренний механизм». С моей точки зрения, даже с учетом того, что все студенты имеют высшее образование, без определенного жизненного опыта восприятие курса затруднительно. Прошу разрешения Учителя посетить ее лекции с тем, чтобы наяву ознакомиться с элитным (без натяжек) обучением. К моему изумлению, она мне отказывает. «Саша, я стесняюсь!». Как говорят, без комментариев...

Неподражаемым примером останутся для меня рабочие мини-семинары в отделе социальных проблем Института экономики и организации промышленного производства. Татьяна Ивановна предварительно знакомит со своим текстом сотрудников, собирает всех за круглым столом и просит высказать замечания. Удивительно другое - она внимательно выслушивает каждого из присутствующих, вне зависимости от его научных заслуг и статуса, делает в блокноте пометки и каждому без исключения подробно излагает свою позицию. Такое уважительное отношение к коллегам дисциплинировало лучше административных взысканий.

Об отношении Татьяны Ивановны к простым людям, к «демосу», как принято говорить, нужно сказать особо. С сегодняшних позиций отношения власть имущих к народу и народа к власть имущим - очень актуальная тема.

Вспоминаю письмо, которое мне прочитала Татьяна Ивановна. Письмо, второе по счету, было от незнакомого ей мужчины, который благодарил Татьяну Ивановну за участие в его судьбе. Человек был на грани суицида, написал полное отчаяния письмо знаменитому Академику. На ответ, думаю, не рассчитывал. Но она ответила, ответила, судя по всему (с содержанием первого письма и ее ответом я не знаком) так психологически тонко, так душевно, что отвела его от опасной черты. Надо уметь так сопереживать, так чувствовать чужую боль, как умела это делать она.

Разные в ее жизни были ситуации. Татьяна Ивановна в гуще политических событий, член Верховного Совета СССР. Звонок от мужчины, рассказывает, что во время демонстрации в Москве (детали я не помню) ОМОН сжал в кольцо людей и долго их не выпускал. Просит Татьяну Ивановну как депутата Верховного Совета СССР поднять вопрос о нарушении принципов демократии на сессии. Звонил он и на следующий день, спрашивал о результатах.

Со всей присущей ей энергией, искренностью и верой в людей она взялась за решение этого вопроса. А на деле оказалась - провокация с целью ее дискредитации. В памяти осталось расстроенное и крайне усталое лицо Татьяны Ивановны...

Она была из другого мира, где доверие к окружающим не являлось недостатком и признаком недалекого ума. Не могла Татьяна Ивановна изменить своим демократическим идеалам, принять ценности «дикого капитализма». Слишком цельная была натура.

В Татьяне Ивановне как профессионале поражало все: всепоглощающая увлеченность и преданность науке, чистота и единство помыслов и дел, поднятые на небывалую высоту (особенно по отношению к нашему времени) научные принципы, наконец, удивительная работоспособность, по признанию Татьяны Ивановны, «семерых мужиков».

Мне не раз приходилось видеть, с каким достоинством и глубокой аргументацией отстаивала она свою точку зрения. Взвешенность и независимость ее суждений и умозаключений были видны любому непредвзятому человеку.

Сказать при этом, что Татьяна Ивановна была полностью независима от общественного мнения, - значит погрешить против истины. Но это касалось в главном не науки, а царивших в ту пору в интеллигентской среде настроений.

Вспоминаю наши диалоги после того, как Татьяну Ивановну выбрали действительным членом Академии наук СССР. Всем известно, что это решение не принималось без согласования с ЦК партии. Ряд ученых, с позиций которых я не согласен до сих пор, считали гражданским долгом Учителя в знак несогласия и протеста отказаться от звания академика. Татьяна Ивановна очень переживала по этому поводу. Лучшим аргументом в споре с ее «нравственными оппонентами» служит вся ее дальнейшая деятельность: вклад в формирование идеалов перестройки, активное участие в обще- 
ственной жизни, отставание неудобной для властей собственной позиции и, как следствие, попадание в «черный список» и потеря привилегий. К слову, от положенной ей по статусу государственной дачи, насколько я знаю, она отказалась сама...

Работала она взахлеб, на износ, без выходных.

— Татьяна Ивановна, Вы почему работаете? Cегодня же выходной.

Отрывается от компьютера, смотрит на меня с легкой грустью:

\section{- Саша, а чем еще жить?}

Помню восторг аспиранта Татьяны Ивановны, В. Федосеева, поступившего в аспирантуру на год раньше меня. Показывает мне порядка 90 страниц (!) текста Татьяны Ивановны, как раз по теме его диссертации. Наверху стоит дата и пометка «Карловы Вары» (она была там в отпуске!).

Как завидовал я Валерию! И как глубоко заблуждался, не понимая, что спустя полгода Учитель спросит его: «Это сделала я, а что сделали Вы?». Попробуйте прокопать канавку рядом со рвом, сравните результаты. Попробуйте создать рядом с большим что-то, пусть и не столь значительное, но свое. Кто пробовал, тот знает - не получится, «снесет в колею».

О научной принципиальности Татьяны Ивановны можно складывать легенды. Через месяц после поступления в аспирантуру написал тезисы на конференцию. Вызывает Татьяна Ивановна:

- Саша, Вы не разделили, что сделано мной, а что - Вами. Следующая такая работа - через мой труп (почти дословно, такой был жесткий урок). К слову, следующая работа (глава в коллективной монографии) вышла в свет только через полтора года.

После окончания аспирантуры прошло 17 лет. Прошу Татьяну Ивановну как научного консультанта работы посмотреть первый вариант (сколько их потом еще было!) моей докторской диссертации. Как всегда, высококлассная работа Учителя, скрупулезный и, как следовало ожидать, нелицеприятный отзыв на восьми страницах.

- Саша, Вы знаете, как я к Вам отношусь, но это - не наука.

Сохранились первые мои научные вирши. На полях пометки Учителя. Наиболее часто встречается: «Непонятно, но занятно!».

Татьяна Ивановна просит меня быстро написать какой-то текст. Не получается. Говорит:

- Саша, Вы никогда не заработаете себе на хлеб писаниной. Вы так медленно пишите...

Спасибо Учителю за школу, за казавшуюся мне тогда чрезмерную требовательность, за необходимость переписывать научные тексты до семи раз.

Трудно оценить человека, его мысли и поступки, если не понимать специфику того времени, в котором он прожил свою активную жизнь. В советские годы залогом успешности (сегодня в это понятие вкладывается совершенно иное содержание) был конформистский по своей сути принцип «Лучше ошибаться с родной партией, чем быть правым одному».

И здесь Татьяна Ивановна выпадала из общего ряда. До сих пор в памяти дружеский шарж на Татьяну Ивановну: в закатанных джинсах бродит она с неводом по морю науки. А впереди - буйки, заплывать за которые, как известно, запрещено. И надпись: «Социальная структура».

- Саша, Вы знаете, как я работаю. Одну ногу ставлю на твердую (имеется в виду официальная позиция) почву, а второй нащупываю - можно или нельзя...

Неудивительно, что в доме Учителя висел в свое время портрет Ю. В. Андропова. Я никогда ее не спрашивал, каковы причины ее особого отношения к столь неординарному политику. Могу только предположить, что не последнюю роль сыграло его заявление о том, что «обществоведы должны быть возмутителями общественного спокойствия». Это было ей близко по духу и по делам.

Ушли былые времена, сменилась формация. Нет в помине в России и цензуры. Но почему-то не оставляет меня равнодушным стихи Л. Авербуха:

Да, под луной ничто не ново.

Стремленье к истине бесплодно.

Тебе дана свобода слова?

Вот и молчи о чём угодно.

До сих пор уроки Учителя остаются актуальными...

Все, кто серьезно относится к науке и тем более работает в этой сфере, знают, какой это тяжелый, порой изнуряющий труд. На ум приходит фраза М. В. Ломоносова: «О солнце я пишу, а солнца я не вижу».

Для Татьяны Ивановны наука была осью, вокруг которой вращалась вся её жизнь. Но с какой, по крайней мере внешне, удивительной легкостью она несла этот крест! Никогда, даже в периоды ее болезни, не слышал я от нее жалоб на непомерную тяжесть интеллектуального труда.

Пытаюсь завести с ней разговор о предстоящей монографии, о том, в каком направлении надо бы работать.

- Саша, пойдемте лучше в сад, я покажу Вам, какой вырос у меня помидор. Видимо, сказываются крестьянские корни моего отца (профессора, если мне не изменяет память, декана физического факультета Московского госуниверситета). Смеется...

А помидор был граммов на 600 и на вкус хорош! 
Гражданская позиция Татьяны Ивановна на происходящие в обществе и науке негативные процессы не заставила себя долго ждать.

Со свойственной ей проницательностью она говорила мне: «Наша с Вами жизнь, Саша, потеряла всякий смысл. Планка науки упала ниже плинтуса. Половина работ собрана из старья, половина написана по заказу...». «Не люби себя в науке, люби науку в себе» - это о ней, о моем Учителе - Татьяне Ивановне Заславской.

Обращаюсь к Учителю как одному из идеологов необходимости перемен в стране:

- Татьяна Ивановна, в чем же был просчет? Почему перестройка «пошла не в ту сторону»?

- Мы, Саша, недооценили ту огромную массу негатива, которая накопилась в обществе к началу перестройки. Это не афишировалось, и ученые знать об этом не могли. Когда лопнули железные обручи, сдерживающие «бочку с негативом» (вот яркий пример образного мышления Учителя), мы получили то, что имеем...

Продолжая сегодня мысленный диалог с Учителем, я бы хотел высказать известную мысль о том, что революцию готовят и осуществляют романтики (подобные моему Учителю), а пользуются ее результатами подлецы. Современная жизнь, к сожалению, подтверждает этот тезис.

Каюсь, моего жизненного опыта тогда не хватило, чтобы осознать глубину этих (и не только этих!) прогнозов и оценок Учителя. С возрастом многое начинаешь воспринимать по-другому. Отдельные высказывания, фразы, брошенные Учителем мимоходом, в конце концов ее настроение становятся мне сегодня понятнее и ближе.

В последние наши встречи Татьяна Ивановна говорила мне: «Саша, Вы уже не мой ученик, Вы - мой друг!». Так она и подписывала мне свои книги.

Меня и тогда, и сейчас не покидало чувство неловкости. Для меня Татьяна Ивановна была и остается Учителем, но не в узком понимании этого слова, а Учителем по жизни.

Пытаюсь ответить на вопрос, что привнесла в мою жизнь Татьяна Ивановна, влияние которой я испытываю до сих пор:

- Настоящую роскошь - роскошь человеческого общения (А. Экзюпери)? Бесспорно!

- Смыслообразующее начало жизни, не оставившее места разъедающей душу скуки? Hem coмнений!

— Должную квалификацию, позволившую мне всю последующую трудовую жизнь не думать о хлебе насущном? Само собой!

- Прививку от наукообразия и научных фейков? И это тоже!

И многое-многое другое, что я не осознаю сегодня, но надеюсь еще понять, если так будет угодно судьбе. 